\title{
Biarkan Perempuan Bicara: Analisis Kekuatan Metode Life History dalam Menghadirkan Pengalaman dan Pengetahuan Perempuan dalam Penelitian Ann Goetting
}

\author{
Ita Musarrofa \\ Universitas Islam Negeri Sunan Ampel, \\ Surabaya - Indonesia \\ email: itaisme@gmail.com
}

\begin{abstract}
Women's experience and knowledge are two substantive things that must be a concern in order to reconstruct the reality of women, in order to overcome the bias of the roles of men and women in life. This paper aims to examine subjective methods that are able to see the reality of women from the lens of women's experience and knowledge so that women have strategic value in their own lives. This study uses field research methods, with data collection techniques from a variety of narratives of women's life history narratively with life history data analysis techniques. This study produces findings that the method of life history is able to identify the subjective experiences of women in constructing their own reality, based on the root experiences of violence that befell them. Second, women's experiences and knowledge about violence can be utilized as a conscious effort to deal with violence, dare to speak out injustice, and rise from the violence they experienced.
\end{abstract}

Keywords: women's experience and knowledge; life history

Abstrak: Pengalaman dan pengetahuan perempuan merupakan dua hal substantif yang harus menjadi perhatian dalam rangka merekonstruksi realitas perempuan, guna mengatasi adanya bias peran laki-laki dan perempuan dalam kehidupan. Tulisan ini bertujuan untuk mengkaji metode subyektif yang mampu melihat realitas perempuan dari lensa pengalaman dan pengetahuan perempuan sehingga perempuan memiliki nilai strategis dalam kehidupannya sendiri. Kajian ini menggunakan metode field research, dengan teknik pengumpulan data dari berbagai rentetan sejarah kehidupan perempuan secara naratif dengan teknik analisis data life history. Kajian ini menghasilkan temuan bahwa metode life history mampu mengidentifikasi pengalaman subyektif perempuan dalam membangun realitas mereka sendiri, berdasarkan pada akar pengalaman kekerasan yang menimpanya. Kedua, pengalaman dan pengetahuan perempuan mengenai kekerasan dapat dimanfaatkan sebagai usaha sadar menghadapi kekerasan, berani menyuarakan ketidakadilan, dan bangkit dari kekerasan yang dialaminya.

Kata Kunci: pengalaman dan pengetahuan perempuan; sejarah hidup 


\section{A. Pendahuluan}

Terlahir sebagai perempuan berbeda dengan terlahir sebagai laki-laki. Struktur sosial yang berbeda bagi dua jenis kelamin ini membuat pengalaman hidup keduanya juga berbeda. Kesadaran akan perbedaan posisi sosial kedua jenis kelamin ini melahirkan pemikiran untuk mengembangkan studi tersendiri tentang perempuan. Langkah ini merupakan kritik terhadap ilmu sosial di masa lalu yang melakukan penelitian dengan kaca mata laki-laki tetapi kemudian digeneralisasikan sebagai berlaku bagi laki-laki dan perempuan. ${ }^{1}$ Perspektif lakilaki tentang realitas dapat benar bagi laki-laki, tetapi kurang benar bagi perempuan. Karenanya, fokus studi perempuan adalah meneliti, mempelajari, serta memahami pengalaman perempuan dalam rangka mengartikan dunia realitas perempuan. ${ }^{2}$

Mengkonstruksi realitas kehidupan perempuan tentu bukanlah persoalan mudah, terdapat unsur-unsur yang sangat luas yang harus diidentifikasi oleh peneliti, seperti unsur ekonomi, budaya, agama, politik. Untuk memahaminya harus pula dilihat kaitan antar unsur tersebut. ${ }^{3}$ Karena kompleksitas realitas kehidupan perempuan, Saptari dan Holzer mengatakan bahwa salah satu tugas penting studi perempuan ialah mengangkat pengalaman dan pengetahuan perempuan yang tersembunyi dalam usaha menghilangkan ketaktampakan mereka dalam hasil penelitian dan teori-teori ilmu sosial dan untuk memperoleh paradigma feminis baru. ${ }^{4}$

Pengalaman dan pengetahuan perempuan merupakan dua hal substantif yang harus menjadi perhatian dalam rangka merekonstruksi realitas perempuan. Pengalaman dan pengetahuan merujuk pada hal yang sifatnya subjektif, hal ini dimaksudkan untuk mengatasi adanya bias laki-laki dalam studi perempuan yang cenderung mengingkari adanya perspektif perempuan, padahal banyak fakta yang sangat membutuhkan alasan kaum perempuan sendiri untuk memahaminya.

\footnotetext{
1Saparinah Sadli, "Pengantar," dalam Perempuan, Kerja dan Perubahan Sosial, Sebuah Pengantar Studi Perempuan, Ratna Saptari dan Brigitte Holzner (Jakarta: Pustaka Utama Grafiti, 1997), vi.

${ }^{2}$ Sadli.

3Irwan Abdullah, "Penelitian Berwawasan Gender dalam Ilmu Sosial," Humaniora 15, no. 3 (2003): 265-75, https://doi.org/10.22146/jh.794.

${ }^{4}$ Ratna Saptari dan Brigitte M. Holzner, Perempuan, Kerja, dan Perubahan Sosial: Sebuah Pengantar Studi Perempuan (Jakarta: Pustaka Utama Grafiti, 1997), 498.
} 
Selain itu, pendekatan subjektif sangat dibutuhkan dalam teori-teori sosial untuk mengupas lapis demi lapis makna yang ada. Dalam studi perempuan, pendekatan subjektif berangkat dari asumsi bahwa perempuan merupakan kelompok yang sadar dan memahami posisi struktural dan kulturalnya di masyarakat sehingga pengalaman subjektifnya juga sah menjadi batu uji bagi teori-teori tentang perempuan yang sudah dikembangkan. Pendekatan subjektif juga bermanfaat dalam menghadirkan perspektif insider tentang alasan yang mendasari suatu praktik sosial yang diwujudkan oleh perempuan serta dapat membangun konsep, nilai, dan ukuran-ukuran yang didefinisikan oleh perempuan sendiri. Ukuran-ukuran inilah yang kemudian digunakan untuk "mengukur" posisi kaum perempuan. Karena dalam banyak hal selama ini, ukuran yang dikenakan kepada kaum perempuan merupakan ukuran laki-laki yang lebih sesuai untuk kaum laki-laki. ${ }^{5}$

Metode penelitian yang mengeksplorasi pengalaman dan pengetahuan individu adalah metode life history. ${ }^{6}$ Di samping life history, terdapat pula biografi dan autobiografi yang sama-sama bertujuan mengkaji secara mendalam kehidupan seseorang. Ketiganya berbeda dilihat dari pembuatnya. Jika biografi ditulis oleh orang lain mengenai kehidupan seseorang, maka autobiografi adalah karya tulis seseorang mengenai dirinya sendiri. Sedangkan life history adalah sebuah kerja interaktif antara penulis dan pencerita; life history adalah kolaborasi dua orang, yaitu insider yang bercerita tentang diri dan masyarakatnya dan outsider yang menanyakan pertanyaan-pertanyaan berdasarkan kerangka referensinya. Untuk itu, dokumen life history sering kali disebut dokumen interaksi (document of interaction). ${ }^{7}$

Artikel ini bermaksud mengkaji tentang apa dan bagaimana menggunakan metode life history dalam menghadirkan pengalaman dan pengetahuan perempuan melalui telaah pustaka terhadap tulisan-tulisan yang mengkaji secara mendalam metode life history, yaitu Norman K. Denzin, ${ }^{8}$ Robert V. Labaree, ${ }^{9} \mathrm{~J}$.

\footnotetext{
${ }^{5}$ Saptari dan Holzner, 268-9.

${ }^{6}$ Norman K. Denzin, Interpretive Biography (Newbury Park, London, New Delhi: Sage Publication Inc., 1989), 8.

${ }^{7}$ Margaret Strobel dan Sarah Mirza, ed, Three Swahili Women, Life Histories from Mombasa, Kenya (Bloomongton, Indianapolis: Indiana University Press, 1989); lihat juga: Michael V. Angrosino, Documents of Interaction: Biography, Autobiography and Life History in Social Science Perspective (Florida: University of Florida Press, 1989), 3.

${ }^{8}$ Denzin, Interpretive Biography.
} 
Ita Musarrofa

Amos Hatch dan Richard Wisnieuwski (ed.), ${ }^{10}$ Ken Plummer, ${ }^{11}$ Michael V. Angrosino, ${ }^{12}$ dan Dan Goodly, Rebecca Lawthom, Peter Claough dan Miclele Moore. ${ }^{13}$ Tulisan ini juga melihat bagaimana aplikasi metode life history melalui telaah terhadap penelitian Ann Goetting. ${ }^{14}$

\section{B. Apa Life History?}

Terdapat banyak sekali istilah yang berdekatan dengan istilah life history. Karena kedekatan maknanya, istilah-istilah tersebut sering kali dipertukarkan. Ken Plummer salah satunya yang menyamakan istilah life history dengan life narrative, self stories, my stories, autobiografi, oral histories, personal testament, dan life documents. Semua istilah itu memiliki fokus yang sama, yaitu menghadirkan pandangan subjektif informan dan merupakan catatan tentang kehidupan seseorang dengan menggunakan kata-katanya sendiri. 15

Menurut Janet L. Miller, life history merupakan salah satu variasi konseptual dan metodologis dari biografi yang muncul karena pengaruh berbagai disiplin. Variasi lain metode biografis (biographical method) adalah life story, life writing, narrative, oral history, memoar, dan lain-lain. ${ }^{16}$ Hal yang sama dikatakan Ken Plummer, bahwa masing-masing disiplin mempunyai tujuan berbeda-beda dalam menggunakan document of life tersebut. Seorang sejarawan menggunakannya untuk menjelaskan masa lalu. Seorang psikiatri menggunakannya untuk memeriksa dinamika yang menekan ketidaksadaran. Seorang antropolog membuat budaya sebagai target utama investigasi di mana document of life adalah bagiannya. Bagi seorang sosiolog, human document adalah catatan

\footnotetext{
${ }^{9}$ Robert Labaree, "Encounters with the Library: Understanding Experience Using the Life History Method," Library Trends 55, no. 1 (1 Juni 2006), https://doi.org/10.1353/lib.2006.0048.

${ }^{10} \mathrm{~J}$. Amos Hatch dan Richard Wisnieuwski, Life History and Narrative: Question, Issues, and Exemplary Works (London: The Falmer Press, 1995).

${ }^{11}$ Ken Plummer, Document of Life 2: An Invitation to A Critical Humanism (London, Thousand Oaks, New Delhi: Sage Publication Inc., 2001).

${ }^{12}$ Angrosino, Documents of Interaction: Biography, Autobiography and Life History in Social Science Perspective.

${ }^{13}$ Dan Goodley et al., Researching Life Stories: Method, Theory, and Analyses in a Biographical Age (London, New York: Routledge Falmer, 2004), https://doi.org/10.4324/9780203413371.

${ }^{14}$ Ann Goetting dan Caroline Jory, Getting Out, Life Stories of Women Who Left Abusive Men (New York: Columbia University Press, 1999).

15Plummer, Document of Life 2, 18-9.

16Janet L. Miller, "Biography," dalam The SAGE Encyclopedia of Qualitative Research Methods, ed. Lisa M. Given, Vol 1 (Los Angeles, London, New Delhi, Singapore: Sage Publication Inc., 2008), 61.
} 
pengalaman individu yang menerangkan tindakan individual sebagai agen manusia dan sebagai partisipan dalam kehidupan sosial. Bagi seorang biografer sastra, tugas utamanya adalah mengeksplorasi hubungan antara diri dengan kehidupan di masa lalu dan dunia luar. Bagi seorang geneolog, tugasnya adalah untuk menggali sejarah leluhur. ${ }^{17}$ Norman K. Denzin mencoba mendefinisikan istilah-istilah yang sangat banyak tersebut. Ia menyimpulkan bahwa setiap istilah mengandung istilah yang lain, makna masing-masing tumpah pada masing-masing yang lain, usaha untuk memberikan makna pasti pada masingmasing istilah tidak akan pernah berhasil. ${ }^{18}$

Istilah life history juga pernah diteliti hubungannya dengan istilah narrative oleh J. Amos Hatch dan Richard Wisniewski. ${ }^{19}$ Seorang responden dalam penelitian itu, yaitu Pauline Chinn, mendefinisikan life history sebagai cerita tentang diri referensial. Dengan cerita itu, pengarang dan pencerita membentuk identitas dan pandangan dari seorang individu yang secara historis disituasikan dalam budaya, waktu, dan tempat. Responden lain, Paul Schempp, mengatakan hal yang sama bahwa life history adalah cerita-cerita tentang kehidupan masyarakat. Cerita-cerita itu adalah narrative. Namun, yang membedakan life history dengan bentuk-bentuk narrative lainnya adalah keterhubungan antara kejadian-kejadian dalam kehidupan seseorang dengan peristiwa-peristiwa sosial. Hidup dilihat sebagaimana dijalani dalam waktu, tempat, dan keadaankeadaan sosial tertentu, daripada hanya koleksi atau kumpulan peristiwa. ${ }^{20}$

Jadi, perbedaan paling penting antara life history dan narrative adalah peranan konteks. Life history menempatkan catatan-catatan interpretasi narrative dalam konteks yang lebih luas-personal, historis, sosial, institusional, dan politis. Selain itu, keduanya juga dibedakan berdasarkan tujuannya. Kalau narrative fokus pada penciptaan makna pengalaman individual, maka life history

${ }^{17}$ Plummer, Document of Life 2, 17-8.

18Denzin, Interpretive Biography, 27-49.

${ }^{19}$ Keduanya meneliti perbedaan life history dan narrative dengan cara memberikan daftar pertanyaan kepada 79 orang sarjana di bidang life history dan narrative, dan 22 orang diantaranya memberikan respons. Pertanyaan yang diajukan seputar perbedaan life history dan narrative, hubungan antara life history dan narrative dengan pendekatan-pendekatan kualitatif lainnya, persoalanpersoalan yang berhubungan dengan penelitian di bidang ini, serta hubungan life history dan narrative dengan post-strukturalisme. Lihat Hatch dan Wisnieuwski, Life History and Narrative, 113-4.

${ }^{20}$ Hatch dan Wisnieuwski, 115. 
menggambarkan pengalaman-pengalaman individual untuk menciptakan makna kontekstual yang lebih luas. ${ }^{21}$

Penekanan yang sama dikatakan Ken Plummer dan Norman K. Denzin tentang life history. Ken Plummer mengatakan bahwa life history selalu mendorong kita ke dalam fokus ganda dalam sejarah; pada perhatian terhadap waktu dalam hidup - bagaimana hidup dijalani selama beberapa fase, karir, siklus, dan tingkatan-tingkatan; dan terhadap waktu di luar hidup, tentang bagaimana momen terbaik sejarah memainkan perannya dalam membentuk kehidupan. Lebih luas lagi, penelitian life history selalu mengambil fokus pada perubahan sejarah, yang bergerak antara perubahan sejarah biografis seseorang dan sejarah sosial dalam rentang hidupnya. Mengumpulkan life history selalu akan membawa subjek bergerak antara perkembangan siklus hidupnya sendiri dan cara-cara di mana situasi dan krisis internal menimpanya. Sebuah life history tak dapat diceritakan tanpa referensi konstan terhadap perubahan sejarah. Fokus life history terhadap perubahan harus dilihat sebagai nilai terbesar life history. ${ }^{22}$

Dari penjelasan-penjelasan di atas, dapat dilihat perbedaan penting life history dari metode-metode lainnya dalam lingkup metode kualitatif. Life history bertujuan menghadirkan pandangan subjektif seseorang mengenai kehidupan yang dijalaninya dengan menggunakan kata-katanya sendiri. Life history tidak membahas seluruh sejarah kehidupan seseorang, tetapi terfokus pada satu poin penting dan menempatkannya dalam waktu, tempat, dan keadaan-keadaan sosial tertentu.

Life history sebagai salah satu metode yang termasuk ke dalam rumpun metode kualitatif memiliki tiga keistimewaan sebagaimana digambarkan oleh Cole dan Knowles. Pertama, metode life history dimaksudkan untuk mempertajam pemahaman mengenai kompleksitas interaksi antara kehidupan individu dengan konteks sosial dan institusional tempat dia hidup. Kedua, metode ini memberikan suara pada kehidupan yang dialami, khususnya bagi mereka yang suaranya tidak didengar atau dengan sengaja diacuhkan bahkan ditekan. Ketiga, penelitian ini juga menceritakan kisah-kisah masyarakat menggunakan katakata mereka sendiri. Dengan cara ini dapat menyampaikan sebuah representasi

\footnotetext{
21 Hatch dan Wisnieuwski, 116.

${ }^{22}$ Hatch dan Wisnieuwski, 40.
} 
pengalaman manusia dan membawa pembaca memasuki proses interpretatif. Pembaca diundang untuk membuat makna dan membentuk penilaian didasarkan pada interpretasi terhadap teks sebagaimana ditampilkan melalui realitas mereka sendiri. ${ }^{23} \mathrm{Hal}$ senada dengan poin ketiga di atas dikatakan Norman K. Denzin. Menurutnya, ketika seorang penulis menulis biografi, dia menuliskan dirinya sendiri ke dalam hidup subjek yang sedang ditulisnya. Ketika pembaca membaca teks biografi, teks itu dibaca melalui hidup si pembaca. Karena itu, penulis dan pembaca bersekongkol dalam menciptakan kehidupan yang mereka tulis dan mereka baca. ${ }^{24}$

Menurut catatan Norman K. Denzin, metode life history, biografi, case history, dan etnografi adalah bagian dari sejarah sosiologi sejak tahun 1920 dan 1930 ketika para sosiolog Universitas Chicago berada di bawah pengaruh Park, Thomas, Znaniecki, dan Burgess. Para sosiolog generasi berikutnya berpaling dari metode ini, mereka lebih memerhatikan masalah-masalah pengukuran, validitas, reliabilitas, dan respon terhadap questioner tentang perilaku, metode survei, eksperimen laboratorium, perkembangan teori, dan indikator-indikator konseptual. Beberapa penulis mengombinasikan ketertarikan tersebut dengan metode life history-biografi, tetapi sering kali menghasilkan peremehan dan pendistorsian tujuan-tujuan asli metode ini. ${ }^{25}$

Pada dekade terakhir, menurut Denzin, para sosiolog dan sarjana-sarjana dari disiplin lain menunjukkan minat baru pada metode biografis. Pada tahun 1978, kelompok "Biography and Sociology" dibentuk di dalam International Sociological Association (ISA) di Uppsala Swedia. Berturut-turut kelompok ini menerbitkan jurnal dan newsletter, seperti Life Stories, jurnal mengenai sejarah oral masyarakat, Oral History yang mempublikasikan materi-materi life historybiografis secara reguler. Di bidang sosiologi dan antropologi, terbit jurnal Qualitative Sociology, The Jurnal of Contemporary Ethnography, Dialectical Anthropology, dan Current Anthropology yang sering menerbitkan artikel-artikel berkaitan. ${ }^{26}$

\footnotetext{
${ }^{23}$ Sifat-sifat life history yang digambarkan Cole dan Knowles di atas dikutip oleh Labaree, "Encounters with the Library: Understanding Experience Using the Life History Method."

${ }^{24}$ Denzin, Interpretive Biography, 26.

${ }^{25}$ Denzin, 8.

26Denzin.
} 


\section{Karakteristik Desain Penelitian Life history}

\section{Teknik dan Taktik Interview}

Maksud dari penggunaan teknik interview dalam penelitian life history adalah untuk membuat profile mendalam mengenai pengalaman hidup responden sesuai dengan masalah yang diteliti. Dalam melakukan interview life history, Robert V. Labaree mengharuskan terlebih dahulu membuat panduan wawancara, karena maksud dari penelitian adalah untuk mengadakan eksplorasi terhadap pengalaman hidup tertentu saja, bukan untuk mengembangkan profile biografi yang komprehensif mengenai kehidupan individu. Tantangan bagi peneliti life history adalah mengembangkan panduan interview yang memunculkan kesempatan untuk memahami sebanyak mungkin momen penting dalam kehidupan individu. Interview tersebut tidak boleh terlalu terbuka dan tidak fokus sehingga memunculkan informasi-informasi yang tidak dibutuhkan. ${ }^{27}$

Sifat dasar wawancara yang terbuka dan tak terstruktur seperti itu, membutuhkan teknik mendengar aktif. Teknik ini penting diaplikasikan agar bisa mendengar dengan baik makna penting yang telah dikatakan dan untuk mencari pemahaman yang mendalam tentang pengetahuan yang diceritakan orang lain. selain itu, selama melakukan wawancara life history, seorang peneliti harus sadar akan fakta bahwa informasi baru dapat muncul kapan saja. Jadi, rekaman tape tidak bisa menggantikan teknik mendengar aktif. Penting pula dicatat, bahwa karena hasil wawancara life history merupakan hasil penemuan yang diperoleh dari sebuah perjalanan diskursif yang terkonstruksi, maka makna dan pengetahuan baru tidak hanya muncul dari hubungan intersubjektif antara peneliti dan responden, bahkan interaksi itu sendiri menjadi satu kontribusi dalam memunculkan pengetahuan dan pemahaman tambahan. ${ }^{28}$

Teknik wawancara khas life history lainnya adalah bagaimana menunjukkan empati terhadap orang-orang yang diwawancarai. Empati melibatkan lebih dari sekedar isyarat afirmatif non-verbal dan pengakuan yang dibuat selama interview. Mengenai peran empati ini, Robert V. Labaree mengutip kerangka konseptual Bondi. Bondi mencatat, bahwa empati sangat penting dalam

\footnotetext{
${ }^{27}$ Labaree, "Encounters with the Library..." 5.

${ }^{28}$ Labaree.
} 
wawancara kualitatif karena memungkinkan terciptanya ruang inter-personal dan intra-psikis tempat persamaan dan perbedaan dapat dimobilisasi, diekspresikan dan dieksplorasi. Inilah mengapa mempraktekkan teknik mendengar aktif sangatlah penting. ${ }^{29}$

Suatu wawancara adalah definisi kerja antara responden sebagai pembicara dan peneliti sebagai pendengar. Jadi, ketika membagi pikiran dan perasaan mengenai pengalaman pribadi, responden ingin merasakan bahwa ia telah dimengerti dan apa yang telah ia katakan memberikan makna khusus bagi peneliti. Hal ini mengharuskan investigator mengidentifikasikan diri dengan orang yang sedang diwawancarai sementara ia tetap sadar dengan perasaannya sendiri agar tetap fokus dengan tanggung jawabnya melaksanakan rencana penelitian. Jadi, lebih dari sekedar terjadi secara simultan, empati merupakan sebuah pergerakan antara posisi ketenggelaman dalam cerita orang dan mengambil jarak secara objektif oleh seorang peneliti. Bondi, sebagaimana dikutip Robert V. Labaree menyimpulkan, bahwa pergerakan ini menciptakan apa yang digambarkan sebagai ruang manufer atau semacam ruang psikis, tempat ketertarikan dan kesamaan dapat dipertimbangkan dan pada saat yang sama memelihara perasaan berbeda dan berjarak. Empati dapat juga dipikirkan sebagai istilah ruang psikis, tempat pergerakan antara banyak posisi mungkin dilakukan. Karena penelitian life history dimaksudkan untuk menyelidiki secara mendalam pengalaman hidup orang lain, maka empati yang dibingkai dengan cara ini dapat menjadi pendekatan yang berguna dalam mengadakan wawancara yang efektif dan penuh makna. ${ }^{30}$

\section{Mengelola dan Menganalisis Data}

Meskipun tindakan menganalisis data dapat berbentuk bermacam-macam, tetapi biasanya dimulai dengan melakukan koding terhadap data menjadi unitunit analisis yang penuh makna. Koding bagi peneliti, merupakan tingkatan awal menginterpretasikan bagaimana responden memandang dunia dan tingkatan awal mengkonstruksi sebuah cerita yang memberi gambaran kepada pembaca tentang kehidupan yang dialami orang lain. Menetapkan kode-kode melibatkan mengurangi teks ke dalam kategori yang dianggap penting oleh peneliti dalam

\footnotetext{
${ }^{29}$ Labaree.

${ }^{30}$ Labaree.
} 
hubungannya dengan masalah yang diteliti. Analisis dimulai dengan mengembangkan kode-kode sebelum menguji data yang sekarang atau peneliti dapat memilih pendekatan induktif yang memungkinkan kode-kode muncul selama pengujian terhadap teks. ${ }^{31}$

Langkah analisis yang terakhir adalah merangkai kode-kode menjadi kelompok yang luas yang menunjukkan tema umum yang menginformasikan pemahaman yang lebih mendalam mengenai problem penelitian yang sedang diinfestigasi. Mengidentifikasikan kategori-kategori konseptual membantu peneliti membedakan di mana commonalitas, perbedaan-perbedaan, pola-pola, dan struktur dari fenomena yang mungkin ada. Hal ini dapat menciptakan kesempatan untuk menerbitkan pertanyaan-pertanyaan penelitian baru, untuk menunjukkan hubungan antar data, untuk menghapus atau menambah kode dan untuk merangkai kode ke dalam aturan-aturan hierarkis. ${ }^{32}$

Tugas paling penting bagi peneliti dalam mengelola data kualitatif adalah merekam wawancara dan mengorganisasikan seefisien mungkin materi-materi tambahan yang dimasukkan untuk mendukung penelitian. Pengaturan dan pengelolaan yang efektif terhadap data life history sangatlah penting karena dapat memudahkan analisis, interpretasi, dan laporan penemuan yang dapat dipercaya dan penuh makna. Ken Plummer menganjurkan untuk mengelola data menjadi tiga bagian, yaitu: core files, analytic file dan personal log. Pertama, file inti (core file). Data yang dimasukkan dalam file ini adalah data asli dan kaya yang belum diedit. Data ini diatur dan dikatalogkan berdasarkan urutan-urutan yang jelas. Dalam file, ini dibuat pula index yang berisi daftar seluruh dokumen, nama-nama file, dan ciri-ciri lainnya. Kedua, file analisis (analytical file). Data yang dimasukkan ke dalam file ini adalah data yang dibaca berdasarkan konsep dan tema teoretik tertentu yang telah dikembangkan dalam penelitian. Tema kunci di dalam teks dicari agar semua data yang penting dapat dipotong, dijadikan referensi, dan ditempatkan di dalam file analitik atau tematik yang sesuai. Ketiga, personal log merupakan diary pribadi yang berisi catatan tentang perubahan kesan penulis terhadap informan, situasi, kekhawatiran, dan kecemasan penulis sendiri mengenai penelitian yang dijalani. Catatan pribadi ini menjadi bagian penting dari proses penelitian. ${ }^{33}$

\footnotetext{
${ }^{31}$ Labaree.

${ }^{32}$ Labaree.

33Plummer, Document of Life 2, 149-152.
} 
Dalam penelitian kualitatif, khususnya life history, proses mengumpulkan dan menganalisis bukti harus dilakukan secara simultan. Pengumpulan dan analisis simultan terhadap data juga memudahkan eksplorasi kesempatan baru yang mungkin dari pertemuan dengan responden. Cole dan Knowles mengingatkan kita, bahwa peneliti selalu merupakan instrumen kunci dalam analisis penelitian life history, karenanya dibutuhkan kesiapan mental untuk memahami dan menerima kompleksitas tugas, sifat kreatif proses, penggunaan waktu, kesabaran dan komitmen, jika suatu saat terjadi proses yang berbelit-belit dan kacau balau. Kegiatan pengumpulan dan analisis data tak mungkin dipisahkan satu sama lain, keduanya berlangsung secara simultan dan serempak. Kegiatan analisis data, menurut Miles dan Huberman, melibatkan tiga proses: reduksi data, pengujian data, dan penyimpulan (data reduction, data display, and conclusions: drawing/verifying). Pengumpulan data, menurut keduanya, menjadi bagian tak terpisahkan dari proses analisis data. ${ }^{34}$

Dalam menganalisis data yang berupa cerita (narrative), Donald E. Polkinghorne membedakan dua tipe analisis data. Pertama, analisis paradigmatik, yaitu analisis yang dilakukan dengan cara mengakui elemen sebagai anggota sebuah kategori. Melalui analisis ini, cerita dikumpulkan untuk menjadi data penelitian; dari cerita tersebut lalu dicari tema atau gagasan umum yang menyusun cerita. Penemuan tema dilakukan dengan penentuan kategorikategori item data, kemudian dilakukan proses koding, yaitu proses memisahkan data menjadi kelompok-kelompok data, kemudian mengidentifikasikan sifat umum mereka dan memasukkannya sebagai anggota sebuah kategori. ${ }^{35} \mathrm{Kedua}$, analisis naratif yang dijalankan dengan menggabungkan elemen-elemen ke dalam cerita dengan menggunakan plot sehingga menghasilkan satu cerita utuh.

\section{Mempresentasikan Data}

Secara umum, presentasi penemuan-penemuan life history dapat dibingkai dalam satu atau dua cara. Studi dapat menyajikan masing-masing life history

${ }^{34}$ A. Michael Huberman dan Matthew B. Miles, "Data Management and Analysis Methods," dalam Handbook of qualitative research. (Thousand Oaks, CA, US: Sage Publications, Inc, 1994), 428-44; Sanapiah Faisal, "Pengumpulan dan Analisis Data dalam Penelitian Kualitatif," dalam Analisis Data Penelitian Kualitatif: Pemahaman Filosofis dan Metodologis ke Arah Penguasaan Model Aplikasi, ed. Burhan Bungin (Jakarta: Raja Grafindo Persada, 2003), 68-9.

35Donald E. Polkinghorne, "Narrative Conviguration in Qualitative Analysis," dalam Life History and Narrative: Question, Issues, and Exemplary Works, ed. J. Amos Hatch dan Richard Wisnieuwski (London: Routledge Falmer, 1995), 8-16. 
sebagai sebuah kasus spesifik yang diikuti oleh penyajian akhir mengenai isu kritis yang muncul dari analisis data. Pendekatan ini sangat membantu dalam menyoroti keunikan pengalaman individu. Pendekatan lainnya adalah menyajikan temuan-temuan secara tematik dan didukung oleh kutipan cerita yang digambarkan dari wawancara dan sumber lain. Menggambarkan tema kunci yang muncul dari data dapat efektif dalam mempengaruhi kebijakan, karena pengalaman responden dapat dihubungkan secara kontekstual dengan problem-problem tertentu dan asumsi-asumsi.

Tujuan dari laporan kualitatif adalah untuk membawa pemahaman kepada fenomena sosial yang kompleks yang tidak bisa direduksi menjadi hubungan statistikal. Gaya penulisan ini menimbulkan pertanyaan penting mengenai bagaimana menyajikan data life history secara efektif. Misalnya, sebagai instrumen primer dalam interpretasi dan analisis, peneliti harus pandai menjelaskan bias-bias yang mungkin dia miliki mengenai penelitian maupun penemuannya. Mengakui bias yang mungkin ada memberi dukungan keterpercayaan data dan membantu pembaca mengerti keseluruhan proses interpretasi yang digunakan untuk menguji data. Masalah penting lainnya adalah bahwa peneliti harus tahu siapa audien yang dimaksud dan untuk persoalan atau keputusan apakah penelitian ingin digunakan.

Life history adalah metode yang efektif untuk memberikan suara pada mereka yang mungkin tidak dapat dilihat jika menggunakan bentuk lain penelitian kualitatif. Dengan demikian, tantangan menulis life history adalah untuk mengembangkan sebuah cerita yang co-constructed yang memperhatikan dan menyoroti suara dari responden. Selain itu juga mengembangkan cerita yang melibatkan pengarang dalam teks sebagai instrumen kunci dalam analisis dan interpretasi. Tambahan lagi, data mentah tidak bisa menginformasikan praktek bila ia diletakkan di bawah besarnya konteks interpretasi yang dilahirkan oleh peneliti. Hal ini mengharuskan peneliti dengan selektif dalam menyajikan kutipan-kutipan cerita yang mengkontekstualisasikan data. ${ }^{36}$

\section{Problem Insider dalam Penelitian}

Insider dalam penelitian kualitatif menunjuk pada penelitian budaya sendiri atau organisasi sendiri. Sebaliknya, konsep outsider menunjuk pada

\footnotetext{
36Polkinghorne.
} 
tindakan menguji sebuah budaya atau organisasi yang tidak dikenal oleh peneliti. Paling tidak ada empat manfaat menjadi peneliti insider: Pertama, insider memiliki nilai karena peneliti akan sangat mengenal atau familiar dengan setting organisasi dan anggota-anggotanya. Kedua, status insider memiliki nilai karena peneliti dan informan memiliki kesamaan sosial dan pengalaman kerja. Asumsinya adalah, bahwa kesamaan pengalaman dapat membentuk bangunan dasar kepercayaan dan mengembangkan hubungan yang dapat menyumbang terbentuknya pengertian yang mendalam mengenai fenomena yang sedang diinfestigasi. Ketiga, insider menunjukkan bahwa peneliti memiliki pemahaman yang lebih besar mengenai bagaimana menginterpretasikan praktek dan kebiasaan kerja budaya dan memperoleh informasi yang hanya berguna bagi anggota-anggota organisasi. Keempat, insider bernilai karena ia memudahkan refleksivitas. Analisis introspektif yang didasarkan pada pengetahuan insider bisa mengantarkan pada penemuan maksud-maksud yang sangat jelas bagi peneliti dan pemahaman yang lebih dalam bagi proses penelitian. ${ }^{37}$

Status insider sangat situasional dan tergantung pada sasaran pokok dari studi dan tingkatan akses terhadap informan kunci. Pendek kata, ketenggelaman total dalam pengalaman hidup seseorang tidak bisa diraih secara penuh. Jadi, peneliti life history harus secara kontinyu bernegosiasi dengan responden untuk menjamin bahwa kesalingterpercayaan akses dan kejernihan tujuan tetap terjaga. Bersamaan dengan negosiasi secara kontinyu ini terdapat dilema etis dan metodologis, misalnya, seorang outsider harus menghabiskan banyak waktu penting dan energi agar dapat memasuki setting penelitian. Menempatkan diri sebagai insider dapat mengurangi kebutuhan untuk memasuki setting penelitian. Meski demikian, kepercayaan dan kerjasama harus tetap dinegosiasikan karena rekan kerja yang sudah dikenal dijadikan infestigator prinsip dalam organisasi. Tanggung jawab lain dalam mempelajari dan menginterpretasikan komunitas sendiri sangatlah menantang karena kesalahan apapun dalam menyajikan fenomena, baik yang riil maupun dalam persepsi, dapat menimbulkan perasaan dikhianati pada sebagian partisipan. Outsider juga punya tanggungjawab yang sama dalam mencegah kesalahan, tapi mereka bisa keluar dari setting penelitian dan berjarak dengan konsekuensi ketidakakuratan representasi masyarakat dan tempat.

\footnotetext{
37Polkinghorne.
} 
Dilema etis lain menjadi peneliti insider adalah teguran memposisikan dan menyingkap data tanpa sengaja. Hal ini mengacu pada posisi atau status peneliti dalam organisasi dan bagaimana posisi seseorang dalam organisasi itu mempengaruhi respon orang lain terhadap penelitian kita. Dilema lain menjadi insider adalah bisa jadi informan adalah orang yang punya hubungan dekat dengan peneliti. Baik itu teman maupun rekan kerja. Dalam hal ini proses penelitiannya mengharuskan dinamika negosiasi baru antara peneliti dan responden yang tidak hanya sebagai teman atau rekan kerja tetapi juga informan kunci dalam penelitian life history.

Peneliti insider juga harus tetap tinggal dalam komunitas yang diteliti setelah proses penelitian selesai tidak bisa menjauhkan diri dari proses. Bagaimana jika ada reaksi dari mereka yang merasa bahwa kesimpulan dan rekomendasi penelitian tidaklah akurat. Kemungkinan seperti ini mengharuskan peneliti mempertimbangkan secara hati-hati siapa yang berpartisipasi dalam penelitian dan mengukur seberapa sensitifkah temuannya dan pada siapa. Peneliti yang baik akan memastikan bahwa maksud, tujuan dan akibat potensial penelitian pada pembuatan keputusan di masa yang akan datang telah dipahami oleh setiap orang, sebelum, selama, maupun setelah penelitian selesai.

\section{Validitas dan Posisi Peneliti dalam Teks}

Validitas dan tempat peneliti dalam teks sangatlah penting dalam life history. Validitas adalah persepsi bahwa temuan studi berkesesuaian dengan realitas dan apa yang diinfestigasi peneliti benar-benar ada. Sedangkan posisionalitas peneliti adalah tingkatan yang kepadanya tempat pengarang di dalam teks disampaikan. Tierney sebagaimana dikutip oleh Robert V. Labaree mengatakan, bahwa ini adalah masalah khusus yang kita hadapi ketika kita menerjemahkan diri kita dari peneliti menjadi penulis. ${ }^{38}$

Bagi penelitian life history, untuk melengkapi pengetahuan tentang kehidupan yang dialami dan untuk menantang asumsi-asumsi yang sudah sukses tentang praktik saat ini, pengguna penelitian life history harus memiliki keyakinan bahwa infestigator menyajikan realitas yang valid tentang peristiwaperistiwa atau masyarakat. Tantangannya tentu saja bahwa realitas itu subjektif, multidimensional dan berubah-ubah. Oleh karena itu penting sekali dipahami

\footnotetext{
38Polkinghorne.
} 
bahwa tujuan pokoknya bukan untuk menggambarkan realitas, tetapi untuk mengamati dan mendokumentasikan konstruksi individual tentang realitas. Dalam kerangka ini, konsep validitas berhubungan dengan keyakinan yang dimiliki seseorang, bahwa model analisisnya adalah menginfestigasi apa yang dianjurkan untuk diinfestigasi. Tantangan bagi peneliti dalam membangun validitas adalah bagaimana meminimalkan persepsi tentang bias. Tujuannya bukan untuk meraih objektivitas murni tapi untuk mengakui dan mendeskripsikan potensi bias dengan cara yang memungkinkan pembaca menentukan bagaimana bias ini mempengaruhi interpretasi mereka sendiri terhadap temuan.

Bias tidak dapat dibersihkan secara total dari penelitian kualitatif, Ken Plumer mengatakan bahwa bias dapat muncul dari responden, peneliti atau sebagai hasil interaksi antara peneliti dan responden. Plummer menganjurkan beberapa cek validitas yang dapat digunakan untuk meningkatkan kepercayaan terhadap temuan. Misalnya, peneliti dapat menyuruh responden membaca dan menguji secara kritis semua data yang diperoleh dalam studi. Hal ini memungkinkan responden merefleksikan kembali apa yang telah dikatakannya dan untuk menawarkan pengetahuan tambahan yang mungkin lebih mengkontekstualisasikan temuan awal. Peneliti juga dapat membandingkan data life history dengan tipe lain sumber-sumber biografis. Peneliti dapat memperkuat validitas dengan mengumpulkan data dari individu yang mungkin mempunyai pengetahuan tentang situasi yang sama. Hal ini dapat meliputi mengadakan wawancara singkat dan informal dengan orang-orang yang mempunyai latar belakang dan pengalaman yang sama agar kejadian-kejadian kritis yang digambarkan dalam penelitian informan kunci secara independen dapat dikonfirmasi.

Masalah validitas lainnya adalah bagaimana pengarang menyajikan dirinya dalam teks. Seperti baru saja dicatat bahwa tantangan dalam melaporkan penelitian life history adalah menggambarkan cerita yang menjelaskan suara responden sementara juga mengakui peran pengarang sebagai instrumen prinsip dalam analisis dan interpretasi. Tierney, sebagaimana dikutip Robert V. Labaree mengatakan, bahwa peneliti kualitatif secara umum menyajikan dirinya dalam satu di antara tiga cara: sebagai pencerita, sebagai pewawancara dan sebagai partisipan. Sebagai pencerita, pengarang menggunakan 'saya' dalam teks untuk menyajikan satu cerita tentang peristiwa-peristiwa atau masyarakat. 
Peneliti juga dapat mengambil posisi sebagai pewawancara, dialognya dapat berbentuk pertanyaan dan jawaban antara responden dan peneliti. Terakhir, pengarang sering memasuki teks sebagai partisipan, tidak hanya untuk membantu cerita berjalan terus, tetapi juga menempatkan sisi manusia dalam tulisannya. ${ }^{39}$

Tantangan yang mendasari identitas tekstual ini adalah bahwa identitas tekstual tersebut menunjukkan keteguhan pencerita yang benar-benar memasuki lapangan, mengumpulkan dan menganalisis data lalu melaporkan temuan. Peran pengarang dalam mengkonstruk realitas disampaikan sebagai tidak masalah dan seringkali dihilangkan dari teks. Sifat yang dikonstruksi dalam penelitian life history mengharuskan strategi yang lebih hati-hati lagi dalam tidak hanya menyampaikan suara responden tetapi juga mengakui dan menerima suara kedua dalam teks, yaitu suara pengarang. Jika para konsumen penelitian life history bertujuan mengembangkan makna dan membentuk penilaian yang didasarkan pada interpretasi terhadap teks sebagaimana hal ini ditampilkan melalui realitas mereka sendiri.

\section{Penggunaan Metode Life History dalam Penelitian Ann Goetting tentang Perempuan yang Keluar dari Relasi Kekerasan dengan Pasangan}

Ann Goetting menulis buku Getting Out, Life Stories of Women Who Left Abusive Men dari penelitian terhadap kekerasan yang dialami perempuan. Ann Goetting menjelaskan tentang proses awal terjadinya battering atau kekerasan terhadap perempuan. Battering menurutnya merupakan pemaksaan dan intimidasi yang dilakukan laki-laki terhadap perempuan untuk mengontrol perempuan. Proses ini memiliki banyak bentuk dan semakin lama semakin rumit. Perempuan dirayu untuk memasuki relasi kekerasan oleh karena kepribadian laki-laki yang mempesona dan karismatik. Biasanya dimulai dengan kesan pertama yang luar biasa pada diri si laki-laki. Di matanya laki-laki tersebut tampak sebagai sosok yang kuat, dipenuhi oleh pesona dan cinta. Si laki-laki tahu bahwa ia diinginkan dan memberikannya pada si perempuan untuk mengikatnya. Si perempuan lalu merasakan getaran cinta dan merasa beruntung telah menemukan seseorang yang begitu perhatian sehingga ia berkesimpulan bahwa

\footnotetext{
${ }^{39}$ Polkinghorne.
} 
tidak ada orang yang pernah mencintainya dengan cara seperti itu. Inilah menurut Ann Goetting tahap awal terjadinya kekerasan. ${ }^{40}$

Kemudian sesuatu yang menggoncang rasa amannya terjadi. Pandangannya tentang kebahagiaan abadi bersama laki-laki tersebut terancam, ia takut mengecewakan si laki-laki yang menyebabkan ia ditinggalkan nantinya. Ia khawatir ia tidak cukup baik bagi si laki-laki dan tidak cukup mampu merawat si laki-laki, inilah yang menurut Ann Goetting diistilahkan dengan "surga yang hilang". 41

Koleksi cerita hidup perempuan dimaksudkan Goetting untuk alasan personal dan professional yang ingin mengetahui relasi kekerasan yang sesunggguhnya. Biografi yang ada dalam buku Goetting menyajikan prinsipprinsip dan pola-pola terjadinya proses kekerasan dari awal sampai keluar. Latar belakang penulisan buku ini adalah pengalaman pahit masa kecil Goetting sendiri yang mengalami kekerasan yang dilakukan oleh ayahnya. Ia menggambarkan bahwa tak ada satupun anggota keluarga yang tahan dengan kemarahan ayahnya. Kenangan itu terus mempengaruhi setiap anggota keluarga hingga saat ini. Efek yang paling berat dari pengalaman itu adalah kenyataan yang dirasakannya saat ini, yaitu bahkan ia tidak mengerti mengapa itu semua terjadi. Sebagai sarjana bidang studi keluarga dan kriminologis, ia tertarik untuk mengajar dan mempelajari kekerasan dalam keluarga. Dengan cara itu, Goetting mendapatkan kerangka kerja untuk membebaskan dirinya, terutama dari warisan kekerasan di masa kecilnya. Ia melakukan penelitian ini dengan tujuan agar setiap orang mengerti tentang kekerasan dan agar kekerasan itu dihentikan. ${ }^{42}$

Perbedaan etnis, umur, kelas sosial, agama, posisi geografis, orientasi seksual, serta pengalaman mereka merupakan hal-hal yang dipertimbangkan oleh Goetting dalam menentukan informan. Meski demikian, penelitian Goetting ini tidak bermaksud membuat sampel yang representatif, karena tujuan penelitian ini adalah untuk menunjukkan pola-pola serta kasus-kasus yang dapat diambil pelajarannya serta bukan untuk membuat generalisasi. ${ }^{43}$

\footnotetext{
${ }^{40}$ Goetting dan Jory, Getting Out, Life Stories of Women who Left Abusive Men, 16.

${ }^{41}$ Goetting dan Jory.

${ }^{42}$ Goetting dan Jory.

${ }^{43}$ Goetting dan Jory, 17.
} 
Keenam belas informan dicari oleh Goetting dari shelter-shelter korban kekerasan serta organisasi dan agensi yang simpatik terhadap terjadinya kekerasan terhadap perempuan. Mereka dipilih berdasarkan perbedaan etnik kulit hitam dan kulit putih untuk membandingkan pengalaman kekerasan oleh kelompok minoritas. ${ }^{44}$

Pertama kali yang dilakukan Goetting adalah mengumpulkan informasi tentang latar belakang masing-masing perempuan kemudian menggeser perhatiannya pada proses terjadinya kekerasan dan keluar dari peristiwa itu. Teks yang Goetting buat untuk menceritakan cerita perempuan-perempuan yang mengalami kekerasan dan kemudian keluar dari sana, dilengkapi dengan informasi yang diberikan oleh para perempuan tersebut. Juga dilengkapi dengan interpretasi Goetting sendiri. Goetting menggambarkan bahwa masing-masing cerita merupakan hasil kerjasama antara Goetting sendiri sebagai peneliti dan perempuan-perempuan tersebut sebagai informan. Draft pertama yang dihasilkan dari wawancara pertama dengan seorang informan diserahkan kembali oleh Goetting kepada informan tersebut kemudian diperbaiki bersama-sama sampai akhirnya mencapai kesepakatan yang memuaskan kedua belah pihak. Dalam penyebutan identitas informan, Goetting juga meminta izin informan. Sebagian informan ada yang bersedia disebutkan nama aslinya, ada pula yang hanya bersedia dicantumkan nama depannya saja, serta ada pula yang meminta untuk digunakan nama samarannya saja. ${ }^{45}$

Pemilihan Goetting untuk menggunakan metode life history adalah karena menurutnya cara terbaik untuk mengetahui pengalaman manusia, seperti pengalaman melepaskan diri dari kekerasan, adalah melalui pengujian terhadap pengalaman tersebut. Buku kumpulan life history ini menurut Ann Goetting merupakan bentuk perayaan tentang kegigihan, keteguhan hati, dan taktik jitu di bawah kondisi perbudakan patriarkhi yang begitu hebat. ${ }^{46}$

\section{E. Kekuatan Metode Life history dalam Studi Perempuan}

Penelitian yang dilakukan Ann Goetting disajikan dengan menggunakan teknik penyajian data narrative dan bukan paradigmatis. Menggunakan teknik

\footnotetext{
${ }^{44}$ Goetting dan Jory, 19.

${ }^{45}$ Goetting dan Jory, 18.

${ }^{46}$ Goetting dan Jory, 23.
} 
narrative memungkinkan suatu penelitian life history menghasilkan novel antropologis yang penuh makna. Ann Goetting, menyusun kembali cerita perempuan tentang kekerasan yang dialaminya sampai akhirnya keluar dari eskalasi kekerasan tersebut dengan cara membentuk cerita-cerita tersebut menjadi satu cerita hidup yang utuh. Dengan bantuan plot, cerita dimulai dengan pengalaman masa kecil perempuan yang rata-rata berasal dari keluarga yang penuh kekerasan: kekerasan yang pernah dilakukan oleh Ayah dan sikap pasrah sang Ibu berbekas dalam kehidupan berikutnya yang dialami sang anak.

Selanjutnya cerita diikuti dengan pengalaman-pengalaman perempuan untuk pertama kalinya berhubungan dengan laki-laki sampai akhirnya menikah dan punya anak. Penjelasan tentang konflik yang muncul dalam keluarga selanjutnya dikembangkan dengan memaparkan cerita-cerita perempuan bahkan dengan mengutip kata-kata perempuan sendiri yang mengalami perasaan sakit secara mental maupun fisik karena kekerasan yang dilakukan oleh pasangannya. Setelah itu, Ann Goetting menceritakan kesulitan dan usaha-usaha perempuan untuk bisa keluar dari perkawinan.

Sebagaimana dijelaskan Ann Goetting, bahwa cerita ini dibuat bersama para informan, jadi merupakan karya kolaboratif antara Ann Goetting sebagai peneliti dan para informan sebagai pencerita yang ikut mengontrol apa yang ditulis Ann Goetting dengan cara mengoreksi draft dan membuang bagianbagian cerita yang mereka tidak setujui.

Menangkap kompleksitas kehidupan rumah tangga dengan penuh kekerasan di dalamnya, tentu tidak akan menghasilkan cerita-cerita yang kaya sebagaimana yang dilakukan Ann Goetting dalam penelitiannya ini, jika menggunakan metode penelitian yang lain, bukan metode life history. Menggunakan teknik lain tidak akan menghasilkan cerita utuh tentang kejadian yang sebenarnya dialami perempuan dalam rumah tangganya. Dengan menggunakan teknik indepth-interview misalnya, data yang dihasilkan hanya akan berupa potongan-potongan hasil wawancara mendalam tanpa terhubung satu sama lain menjadi satu cerita utuh. Selain itu, menggunakan metode life history memungkinkan peneliti untuk melacak akar pengalaman kekerasan yang menimpa kaum perempuan dalam rumah tangga yang ternyata banyak dipengaruhi oleh kehidupan masa kecilnya sendiri yang penuh kekerasan serta kehidupan masa kecil pasangannya yang juga penuh kekerasan. 
Misalnya pengalaman hidup Jan yang terus berusaha untuk betah tinggal bersama suami yang selalu menghina dan merendahkan karirnya, ternyata juga berakar pada masa kecil Jan yang memiliki seorang Ayah yang sering menghina prestasi yang diraihnya. Tindakan yang diambil Jan juga mencerminkan bagaimana tindakan Ibunya dulu menghadapi ayahnya. Jan sebenarnya perempuan yang sangat pintar dan energik, tetapi kepintarannya seolah-oleh dikebiri dengan hanya cukup bekerja untuk suaminya, seolah-olah suami Jan tidak rela Jan mencapai kesuksesan melebihi dirinya sehingga ia melarang Jan mengembangkan karir di bidang bisnis meskipun ia bergelar MBA.

Demikian juga yang terjadi dengan Kimberly, kekerasan yang ia alami dalam kehidupannya sendiri berakar kuat pada perilaku orang tua yang meninggalkannya di masa kecil. Ia ditinggalkan seolah-olah tidak akan ada orang yang mau menemaninya. Karena perasaan sendiri dan tidak dicintai ini, ketika ada seorang laki-laki yang memperhatikannya, ia sangat tersanjung dan berusaha terus untuk memiliki si laki-laki meskipun si laki-laki hanya menginginkan tubuhnya. Kehidupannya dengan beberapa laki-laki yang lain juga demikian, termasuk dengan laki-laki yang akhirnya menikahinya. Kimberly sangat membutuhkan Grant, karena ia merasa telah mendapatkan cinta sepenuh hati. Grant mengetahui hal itu dan memanfaatkan Kimberly untuk memenuhi kebutuhan hidupnya, baik itu, makan, kendaran maupun kebutuhan seksual, semua diberikan Kimberly asal Grant dapat terus bersamanya. Kimberly menyangka bahwa Grant adalah orang yang tulus, padahal ia hanya menginginkan apa yang menjadi kepentingannya saja termasuk dalam berhubungan seksual.

Selain itu, menggunakan teknik wawancara empatik dalam menggali cerita juga memungkinkan untuk menghadirkan pengalaman terdalam perempuan yang mungkin sulit dikeluarkan jika menggunakan teknik yang lain. misalnya pengalamannya melakukan hubungan seksual yang tidak ia sukai tetapi terpaksa ia lakukan dengan pasrah karena pasangannya menginginkan. Perasaan sakit perempuan secara emosional tergambarkan melalui kata-kata perempuan sendiri yang itu dapat pula dirasakan oleh pembaca. Seperti cerita Kimberly yang dikutip langsung oleh Ann Goetting berikut ini:

Saya berguling dengan air mata terus menetes dan mengizinkannya merayap ke atas tubuh saya dan membanting dirinya sendiri sampai dia selesai. Dia tidak pernah sekalipun peduli saya sedang menangis atau tidak. Yang penting dia bisa menyelesaikan yang dia lakukan pada saya. Beberapa kali hal ini terjadi 
sampai akhirnya menjadi kebiasaan. Dia biasanya mengkritik, berteriak, memulai pertempuran dan mengacuhkan saya. Tetapi ketika ia bangun, ia biasanya menggunakan tubuh saya untuk menampung apapun yang ia butuhkan malam itu. Saya sungguh tidak bisa menjelaskan mengapa saya tidak pernah bangun dan menghentikannya. Dia berbaring di atas saya, saya berharap bisa keluar dari tubuh dan tidak merasakan sakit secara emosial. Saya bisa berkata bahwa pada saat itu, jika kau melihat saya, maka kau seperti melihat ke dasar sumur yang gelap dan kosong. ${ }^{47}$

Cerita Kimberly itu menjelaskan bagaimana perempuan hanya dipandang sebagai obyek seksual, hanya tubuh tanpa hati. Demikian juga cerita Kimberly ketika sebelumnya ia pernah diperkosa oleh Rob, tetangga laki-lakinya yang kemudian memanfaatkan tubuhnya untuk memenuhi kebutuhan akan seks. Sementara Kimberly mengira Rob mencintainya. Contoh lainnya adalah pengalaman hidup perempuan diacuhkan dalam keluarganya sendiri, kebutuhan untuk dicintai, tetapi ia tidak mendapatkan semua itu, tetapi justru kekerasan demi kekerasan yang ia terima.

Pengalaman-pengalaman seperti di atas sangat pribadi dan sulit untuk diungkap, tetapi dengan teknik wawancara life history, dengan teknik mendengar aktif penuh empati, informan dapat menceritakan semua pengalaman tersembunyinya. Dalam mengungkap kasus-kasus KDRT, pengalaman seperti ini tidak bisa diungkap sehingga seringkali kekerasan verbal terhadap perempuan dianggap sebagai hal biasa padahal nyata terbukti dari cerita-cerita perempuan tersebut, hinaan-hinaan, caci-maki lelaki terhadap perempuan sangat berbekas dan mempengaruhi kebahagiaan hidup perempuan. Tentu saja kekerasan verbal ini tidak bisa dianggap hal remeh dan biasa.

Meskipun demikian, penelitian yang dilakukan Ann Goetting tersebut kurang bisa menangkap kompleksitas interaksi antara perempuan dengan lingkungan sosial tempat ia hidup selain hanya lingkungan keluarga dan pekerjaan saja sehingga struktur sosial yang lebih luas tidak bisa tertangkap melalui lensa pengalaman hidup seorang perempuan. Ann Goetting kurang menempatkan cerita dalam situasi historis tertentu seperti perubahan sosial dan lain sebagainya sehingga kontribusi penelitian dalam menjelaskan watak struktur sosial tidak terlihat. Akan tetapi, Ann Goetting dalam pengantarnya

\footnotetext{
${ }^{47}$ Goetting dan Jory.
} 
telah menjelaskan bahwa praktik kekerasan terhadap perempuan lahir dari masyarakat yang patriarkhis.

\section{F. Kesimpulan}

Menangkap kompleksitas kehidupan rumah tangga dengan penuh kekerasan di dalamnya, tentu tidak akan menghasilkan cerita-cerita yang kaya sebagaimana yang dilakukan Ann Goetting dalam penelitiannya ini, jika menggunakan metode penelitian yang lain, bukan metode life history. Menggunakan teknik lain tidak akan menghasilkan cerita utuh tentang kejadian yang sebenarnya dialami perempuan dalam rumah tangganya. Selain itu, menggunakan metode life history memungkinkan peneliti untuk melacak akar pengalaman kekerasan yang menimpa kaum perempuan dalam rumah tangga yang ternyata banyak dipengaruhi oleh kehidupan masa kecilnya sendiri yang penuh kekerasan serta kehidupan masa kecil pasangannya yang juga penuh kekerasan.

Selain itu, menggunakan teknik wawancara empatik dalam menggali cerita juga memungkinkan untuk menghadirkan pengalaman terdalam perempuan yang mungkin sulit dikeluarkan jika menggunakan teknik yang lain. misalnya pengalamannya melakukan hubungan seksual yang tidak ia sukai tetapi terpaksa ia lakukan dengan pasrah karena pasangannya menginginkan. Perasaan sakit perempuan secara emosional tergambarkan melalui kata-kata perempuan sendiri yang itu dapat pula dirasakan oleh pembaca.[s]

\section{Daftar Pustaka}

Abdullah, Irwan. "Penelitian Berwawasan Gender dalam Ilmu Sosial." Humaniora 15, no. 3 (2003): 265-75. https://doi.org/10.22146/jh.794.

Angrosino, Michael V. Documents of Interaction: Biography, Autobiography and Life History in Social Science Perspective. Florida: University of Florida Press, 1989.

Denzin, Norman K. Interpretive Biography. Newbury Park, London, New Delhi: Sage Publication Inc., 1989.

Faisal, Sanapiah. "Pengumpulan dan Analisis Data dalam Penelitian Kualitatif." Dalam Analisis Data Penelitian Kualitatif: Pemahaman Filosofis dan Metodologis ke 
Arah Penguasaan Model Aplikasi, ed. Burhan Bungin. Jakarta: Raja Grafindo Persada, 2003.

Goetting, Ann, dan Caroline Jory. Getting Out, Life Stories of Women Who Left Abusive Men. New York: Columbia University Press, 1999.

Goodley, Dan, Rebecca Lawthom, Peter Clough, dan Michelle Moore. Researching Life Stories: Method, Theory, and Analyses in a Biographical Age. London, New York: Routledge Falmer, 2004. https://doi.org/10.4324/9780203413371.

Hatch, J. Amos, dan Richard Wisnieuwski. Life History and Narrative: Question, Issues, and Exemplary Works. London: The Falmer Press, 1995.

Huberman, A. Michael, dan Matthew B. Miles. "Data Management and Analysis Methods." Dalam Handbook of Qualitative Research, 428-44. Thousand Oaks, CA, US: Sage Publications, Inc, 1994.

Labaree, Robert. "Encounters with the Library: Understanding Experience Using the Life History Method." Library Trends 55, no. 1 (1 Juni 2006). https://doi.org/ 10.1353/lib.2006.0048.

Miller, Janet L. "Biography." In The SAGE Encyclopedia of Qualitative Research Methods, ed. Lisa M. Given, 1 ed. Los Angeles, London, New Delhi, Singapore: Sage Publication Inc., 2008.

Plummer, Ken. Document of Life 2: An Invitation to A Critical Humanism. London, Thousand Oaks, New Delhi: Sage Publication Inc., 2001.

Polkinghorne, Donald E. "Narrative Configuration in Qualitative Analysis." Dalam Life History and Narrative: Question, Issues, and Exemplary Works, ed. J. Amos Hatch dan Richard Wisnieuwski. London: Routledge Falmer, 1995.

Sadli, Saparinah. "Pengantar." Dalam Perempuan, Kerja dan Perubahan Sosial, Sebuah Pengantar Untuk Studi Perempuan, diedit oleh Ratna Saptari dan Brigitte Holzner. Jakarta: Pustaka Utama Grafiti, 1997.

Saptari, Ratna, dan Brigitte M. Holzner. Perempuan, Kerja, dan Perubahan Sosial: Sebuah Pengantar Studi Perempuan. Jakarta: Pustaka Utama Grafiti, 1997.

Strobel, Margaret, dan Sarah Mirza, ed. Three Swahili Women, Life Histories from Mombasa, Kenya. Bloomongton, Indianapolis: Indiana University Press, 1989. 
This page intentionally left blank 